\title{
Increased Control Through Decreased Controls: A Motivational Approach to a Library Circulation Problem
}

\begin{abstract}
An approach to library circulation control based on the motivational factors underlying the borrowers' noncompliance with book withdrawal procedures resulted in the installation of a self-service charge-out system. The number of books withdrawn without being checked out and the number of borrowers who admitted to this practice decline significantly. The statistical procedure (chi square) used to analyze these data tests the null hypothesis that the new system has no effect and that the results are merely due to chance. The conclusion is that there is less than one chance in a thousand of obtaining these statistical values if the system were not actually effective.
\end{abstract}

L LIBRARY CIRCULATION CONTROL has traditionally depended on procedures which policed and restricted the borrowers' activity. ${ }^{1}$ Surveillance and measures which force the borrower to comply with the rules comprise the modus operandi for keeping track of library holdings which leave the library premises. Innovations in control have relied on technological devices ${ }^{2}$ which contribute to increased costs of operation and which seem to stimulate the borrowers to new heights of ingenuity in efforts to outwit the system. ${ }^{3}$

Loretto Heights College, located in Denver, Colorado, is a four-year liberal arts college primarily for women. The enrollment is about 900 .

A library survey in 1968 disclosed that 41 percent of the respondents admitted

Dr. Zelkind is chairman of the psychology department at Loretto Heights College in Denver, Colorado. Mr. Sprug is director of the library at Loretto Heights College in Denver, Colorado. to withdrawing books without charging them out at the circulation desk. The librarian consulted with the senior author, a psychologist, who proposed a circulation control system which addressed itself to the expressed motivation directing this behavior of borrowers.

The hypothesis was that a person-oriented approach concerned with psychological factors would produce better control at lower cost than the object-oriented approach which is conventional.

\section{METHOD}

Subjects. Of the population of 900 , a sample of 254 students provided the data for library survey no. 1; 546 students for the follow-up survey no. 2. An indeterminate number of students composed the group of borrowers of 3,352 books.

Procedure. Data were obtained from two sources. Questionnaires answered anonymously in April 1968 (survey no. 1) and in January 1969 (survey no. 2) 
asked the respondent whether she withdrew a publication, for any reason, without checking it out at the desk. The reasons commonly given for not charging out the books were provided in a checklist on both questionnaires. (See Appendix.)

A count of books returned with and without circulation cards was made in the period April 15 to May 15, 1968, and April 15 to May 15, 1969. Those books with cards were recorded as not having been checked out.

The new control system was put into effect in September 1968. It allows the borrower to charge-out a book by simply removing the card from the book, filling in her name and room number, and depositing the card in any one of the proper receptacles located in various parts of the library. She may also charge-out the book at the desk.

\section{Results}

Table 1 presents the results of the questionnaires circulated prior and subsequent to the do-it-yourself charge-out system. Table 2 shows the number of books returned to the library through the drop chutes, a procedure not requiring contact with library personnel. The number of borrowers not checking out books is reduced significantly $(\mathrm{p}<.001)$, as is the percentage of books borrowed without being checked out $(\mathrm{p}<.001)$.

\section{Discussion}

The original questionnaire asked those who did not check out the books they borrowed to state their reasons. Their responses were (1) no one was at the desk (12 percent); (2) in a hurry (36 percent); (3) need book beyond time

TABLE 1

Respondents to Surveys Determining Number of Borrowers Who Withdrew Books Without Charging Them Out

\begin{tabular}{|c|c|c|c|c|c|c|c|}
\hline \multirow[t]{2}{*}{$\begin{array}{c}\text { Borrowed Books } \\
\text { Without Charging } \\
\text { Them Out }\end{array}$} & \multicolumn{2}{|c|}{$\begin{array}{l}\text { Traditional } \\
\text { Desk Charge- } \\
\text { Out System }\end{array}$} & \multicolumn{5}{|c|}{$\begin{array}{c}\text { Do-It-Yourself } \\
\text { Charge-Out System }\end{array}$} \\
\hline & $\mathrm{N}$ & $\%$ & $\mathbf{N}$ & $\%$ & $\%$ Change & $\mathrm{X} 2^{\circ}$ & $\mathrm{p}^{\circ}$ \\
\hline No & 151 & 59.4 & 370 & 67.8 & 8.1 & 16.06 & $<.001$ \\
\hline Yes & 103 & 40.6 & 176 & 32.2 & 8.1 & & \\
\hline Total & 254 & & 546 & & & & \\
\hline
\end{tabular}

Chi square, the statistical procedure used to analyze these data, tests the null hypothesis that the new system has no effect and that the results are merely due to chance. The conclusion is that there is less than one chance in a thousand of obtaining these statistical values if the system were not actually effective.

TABLE 2

Record of Books Returned via Drop Chutes Before and After New Control System

\begin{tabular}{|c|c|c|c|c|c|c|c|}
\hline & \multicolumn{2}{|c|}{$\begin{array}{c}\text { Traditional Desk Charge- } \\
\text { Out System April } 15 \text { to } \\
\text { May } 15,1968\end{array}$} & \multicolumn{5}{|c|}{$\begin{array}{l}\text { Do-It-Yourself Charge-Out System } \\
\text { April } 15 \text { to May 15, } 1969\end{array}$} \\
\hline & $\mathrm{N}$ & $\%$ & $\mathbf{N}$ & $\%$ & \% Change & $\mathrm{X} 2$ & $\mathrm{p}$ \\
\hline $\begin{array}{l}\text { Books With } \\
\text { Cards }\end{array}$ & 2,324 & 51.0 & 1,183 & 32.1 & 18.9 & 387.22 & $<.001$ \\
\hline $\begin{array}{l}\text { Books Withou } \\
\text { Cards } \\
\text { Total }\end{array}$ & $\begin{array}{r}2,301 \\
4,625\end{array}$ & 49.0 & $\begin{array}{l}2,269 \\
3,452\end{array}$ & 67.9 & 18.9 & & \\
\hline
\end{tabular}




\section{LIBRARY SURVEY NO. 1, APRIL 1968}

Innovations in library procedure will be introduced experimentally this semester to make use of library facilities more convenient for you. In connection with a study now underway you are requested to supply the information below. Do NOT write your name or otherwise identify this information sheet except to indicate your present class level:

$\ldots \ldots$ Sophomore
$\ldots \ldots$ Junior
$\ldots \ldots$ Senior

Check here if you were not a

Loretto Heights student during the 1967-1968 school year

During the past school year many books and periodicals were withdrawn from the library without being checked out at the desk (because no one was at the desk; or for other reasons).

1. Indicate the number of times you (for any reason) withdrew a publication without checking it out at the desk:
0
1 time
2 to 5 times
Always (never charge books out)

2. Indicate the kind of publication taken from the library without oharging it out: periodical book reserve book

3. Indicate the subject area of the material taken from the library without charging it out:

\begin{tabular}{|c|c|c|}
\hline$\ldots \ldots$ art & $\ldots . .$. french & ....... political science \\
\hline . behavioral science & ....... history & ...... psychology \\
\hline biology & ....... math & ... sociology \\
\hline chemistry & $\ldots \ldots$ music & ....... spanish \\
\hline economics & ....... nursing & . . speech \& drama \\
\hline education & ....... philosophy & ... theology \\
\hline ....... english & ....... physics & \\
\hline
\end{tabular}

4. Check the reason(s) for not charging out the publication:

no one at the circulation desk

was in a hurry

needed book beyond the time limit

other (describe, use back side if necessary)

PLEASE RETURN THIS QUESTIONNAIRE TO THE CIRCULATION DESK AS YOU LEAVE THE LIBRARY. 


\section{LIBRARY SURVEY NO. 2, JANUARY 1969}

Please complete this questionnaire and leave it with the attendant as you go from the lecture hall.

Innovations in library circulation were introduced last semester to make use of library facilities more convenient for all. In connection with the study now underway, you are requested to supply the information below. Do NOT write your name or otherwise identify this information sheet except to indicate your present class level.

Check one: Freshman .... Sophomore .... Junior ..... Senior ..... Other

Did .... fill out one of these forms last registration; did not

During the past semester books and periodicals continued to be withdrawn from the library without being checked out either at the desk or by using the self-service check-out system.

1. Indicate the number of times you (for any reason) withdrew a publication without checking it out:
0
1 time
2 to 5 times
Always (never charge books out)

2. Indicate the kind of publication taken from the library without charging it out: periodical book reserve book

3. Indicate the subject area of the material taken from the library without charging it out:

\begin{tabular}{|c|c|c|}
\hline$\ldots \ldots$ art & $\ldots \ldots$ french & ..... political science \\
\hline ....... behavioral science & $\ldots \ldots \ldots$ history & ...... psychology \\
\hline . . . . biology & ......math & ... sociology \\
\hline .... chemistry & ..... music & ...... spanish \\
\hline . economics & ...... nursing & . speech \& drama \\
\hline .... education & ...... philosophy & . . . . . . theology \\
\hline ...... english & ...... physics & \\
\hline
\end{tabular}

4. Check the reason(s) for not charging out the publication:

no one at the circulation desk

was in a hurry

needed book beyond the time limit

other (describe, use back side if necessary)

This is a part of an experiment to compare an honor system with various forms of control systems. Your cooperation is appreciated.

Dr. Irving Zelkind, Director

Mr. Joseph Sprug, Director of Library 
limit (39 percent); (4) all others combined ( 13 percent). These reasons which the subject gave for noncompliance with library procedure do not have the same conceptual basis. Being "in a hurry" is an organismic variable which might be a personality characteristic related to frustration tolerance. "No one at the checkout desk" or "too many borrowers waiting for service" can be viewed as exteroceptive stimuli. However, categories 1 , 2 , and most of 4 were seen as unitary in that they are either discriminative stimuli or organismic factors which combine with the usual desk check-out procedures to produce the negative effect state constituting or accompanying frustration.

The noncompliance with library circulation rules was interpreted as avoidance behavior with regard to this aversive state. The do-it-yourself process, re- quiring only that the borrower sign his name and room number in the book card and deposit it in any of the numerous receptacles provided, eliminates the discriminative stimuli and consequent avoidance behavior exhibited by noncompliant borrowers. Reason 3 is qualitatively different and is not affected by check-out procedures.

A concomitant by-product of the new system was a reduction in the total number of student assistant hours at the circulation desk from approximately 5,000 to 3,000 .

\section{ReFERENCES}

1. "Circulation Control Study," American Library Association Bulletin 54:616 (1960).

2. M. Guards Roberts, "Turnstiles, Electronic Devices, and the Illusion of Security," College \& Research Libraries 29:259-75 (1968).

3. R. F. Clarke and G. Haydee, "Your Charging System: Is It Thief Proof?," Library Journal 91:642-43 (1966). 